\title{
Molecular Survey on Vector-Borne Pathogens in Alpine Wild Carnivorans
}

\author{
Elena Battisti ${ }^{1}$, Stefania Zanet ${ }^{1}$, Sara Khalili ${ }^{2}$, Anna Trisciuoglio ${ }^{3}$, Beatrice Hertel ${ }^{1}$ and \\ Ezio Ferroglio ${ }^{1 *}$
}

${ }^{1}$ Department of Veterinary Science, University of Turin, Turin, Italy, ${ }^{2}$ Department of Parasitology, Faculty of Veterinary Medicine, University of Tehran, Tehran, Iran, ${ }^{3}$ Department of Agricultural, Forest and Food Science, University of Turin, Turin, Italy

\section{OPEN ACCESS}

Edited by:

Donato Traversa,

University of Teramo, Italy

Reviewed by:

Christina Strube,

University of Veterinary Medicine

Hannover, Germany

Carlo Vittorio Citterio,

Istituto Zooprofilattico Sperimentale

delle Venezie, Italy

Anastasia Diakou

Aristotle University of

Thessaloniki, Greece

*Correspondence:

Ezio Ferroglio

ezio.ferroglio@unito.it

Specialty section:

This article was submitted to

Parasitology,

a section of the journal

Frontiers in Veterinary Science

Received: 19 November 2019 Accepted: 02 January 2020 Published: 23 January 2020

Citation:

Battisti $E$, Zanet $S$, Khalili $S$, Trisciuoglio A, Hertel $B$ and Ferroglio $E$ (2020) Molecular Survey on

Vector-Borne Pathogens in Alpine Wild Carnivorans. Front. Vet. Sci. 7:1. doi: 10.3389/fvets.2020.00001
In Europe, free-ranging wildlife has been linked to the emergence of several vector-borne diseases such as rodents for Borrelia burgdorferi s.I. In particular, wild carnivorans are one of the most important sources of emerging zoonotic pathogens worldwide, although little information is available regarding the epidemiology of vector-borne parasites in these animals. Thus, the aim of this paper was to investigate the prevalence of Babesia spp., Anaplasma spp., Ehrlichia spp., Hepatozoon spp. and Leishmania infantum in alpine wild canids and mustelids from Italy. For this study, spleen samples of 157 foxes (Vulpes vulpes), 45 badgers (Meles meles), and 33 wolves (Canis lupus) collected between 2009 and 2017 in Northwest Italy were examined by using conventional PCR. Logistic regression was used to identify possible risk factors for pathogen infections. DNA of any of the tested pathogens was found in more than $90 \%$ of the analyzed animals. In particular, Babesia spp. showed significantly higher prevalence in foxes (89.7\%) and badgers (89.6\%) than in wolves, while the latter were considerably more infected with Hepatozoon canis $(75.8 \%)$ than foxes (5.1\%). None of the badger tested positive for Hepatozoon spp., although they showed high prevalence of Leishmania infantum (53.3\%). Sequencing results revealed the presence, among others, of Babesia vulpes, Babesia sp. isolate badger type A and B, and Anaplasma phagocytophilum. Moreover, previously unreported pathogen/host associations were observed, such as Babesia capreoli in wolves and badgers. The prevalence of vector-borne pathogens observed in the present study is one of the highest reported so far, suggesting the importance of free-ranging carnivorans in the epidemiology and maintenance of the sylvatic cycle of the pathogens. Moreover, several of these pathogens are of particular importance regarding human (A. phagocytophilum, L. infantum) and pet health (L. infantum, B. vulpes).

Keywords: Babesia, Hepatozoon, carnivores, Leishmania, zoonoses, wildlife, vector-borne pathogens

\section{INTRODUCTION}

More than $70 \%$ of zoonotic emerging infectious diseases are caused by pathogens with a wildlife origin, and their impact on human health is increasing (1). In particular, the increased interactions between humans, domestic animals and wildlife, resulting from human population growth, increase of peri-urban sylvatic animals and habitat fragmentation, have been proposed as a leading cause of pathogen emergence (2).

Carnivorans are well-adapted to urban and peri-urban environments, and among the most important sources of zoonotic pathogens such as rabies $(3,4)$. In Europe, sylvatic carnivorans as 
the red fox (Vulpes vulpes) and the European badger (Meles meles) are widely distributed across the continent, with stable or growing populations in urban and suburban areas (5). Furthermore, in recent years we assisted to the recovery of large carnivores in Europe such as the wolf (Canis lupus), which has shown to adapt well to human-dominated landscape (6).

The increase and urbanization of wildlife populations is expected to influence the epidemiology of zoonotic pathogens, as those transmitted by vectors (7). Tick-borne protozoa of the genus Babesia are known to infect both domestic and sylvatic carnivores worldwide $(8,9)$. In Europe, $B$. canis mainly infects dogs, although it has been reported also in the wolf (10) and the red fox (11). Moreover, foxes have been proposed as the natural hosts of $B$. vulpes due to their high infection rate detected and the absence of clinical signs in most of the cases (12). Several genotypes of Babesia spp., phylogenetically related to $B$. microti, have been observed in the European badger, such as Babesia sp. Meles-HU 1 and Babesia sp. badger type A and B $(13,14)$. Similar to Babesia, protozoa of the genus Hepatozoon and bacteria of the genera Anaplasma and Ehrlichia are known to infect domestic and sylvatic mammals, with $H$. canis, A. phagocytophilum, A. platys and E. canis having a considerable impact on carnivores $(15,16)$. Among wildlife, red fox is the most investigated species, showing up to 16 and $90 \%$ of prevalence for A. phagocytophilum (17) and H. canis (18), respectively. Domestic dogs are the main reservoir host for Leishmania infantum, a sandfly transmitted pathogen, although investigations of a recent human leishmaniasis outbreak in Spain have demonstrated the essential role of the Iberian hare (Lepus granatensis) in the maintenance of the sylvatic cycle of the parasite (19). Other studies have focused on the detection of $L$. infantum in wild canids, due to their close phylogenetic relationship with dogs, although their role in the epidemiology of the parasite has not been fully understood (20).
In Italy, scant information regarding the prevalence of vectorborne pathogens in sylvatic carnivorans exist, mainly in the red fox (21-23). Thus, the aim was to investigate the occurrence of selected vector-borne pathogens (Babesia spp., Hepatozoon spp., Anaplasma spp., Ehrlichia spp. and L. infantum) in free-ranging canids and mustelids in the alpine area of Northwest Italy. Notably, these pathogens were chosen due to their significant impact on human and/or animal health, and for their emergence in the studied area $(24,25)$.

\section{MATERIALS AND METHODS}

\section{Study Area}

With more than $25,000 \mathrm{~km}^{2}$ of extension, Piedmont region (Northwestern Italy) is one of the widest regions in Italy. Its territory is predominantly mountainous and hilly, with plains mainly distributed in the southern and eastern parts of the region. At least a third of the land is covered by forest and natural areas, of which 193,000 ha are protected. It is also highly populated, with a mean density of 172 inhabitants $/ \mathrm{km}^{2}$ that reach over 6,000 inhabitants $/ \mathrm{km}^{2}$ in some urban areas. The sampling area ranged from low-urbanized high mountains (up to $1,800 \mathrm{~m}$ a.s.l.) to highly-urbanized plains below $300 \mathrm{~m}$ a.s.l.

\section{Sampling}

For this study, 235 wild carnivorans ( 157 foxes, 45 badgers and 33 wolves) were collected in the period between 2009 and 2017 (Figure 1). All the animals were road-killed, with the exception of red foxes that were culled during the official hunting seasons as part of the culling program for fox population control, and carcasses were brought to the Department of Veterinary Science, University of Turin, for necropsy.

For each animal, information such as age (estimated by dental conditions and body size measurements), sex and area of origin

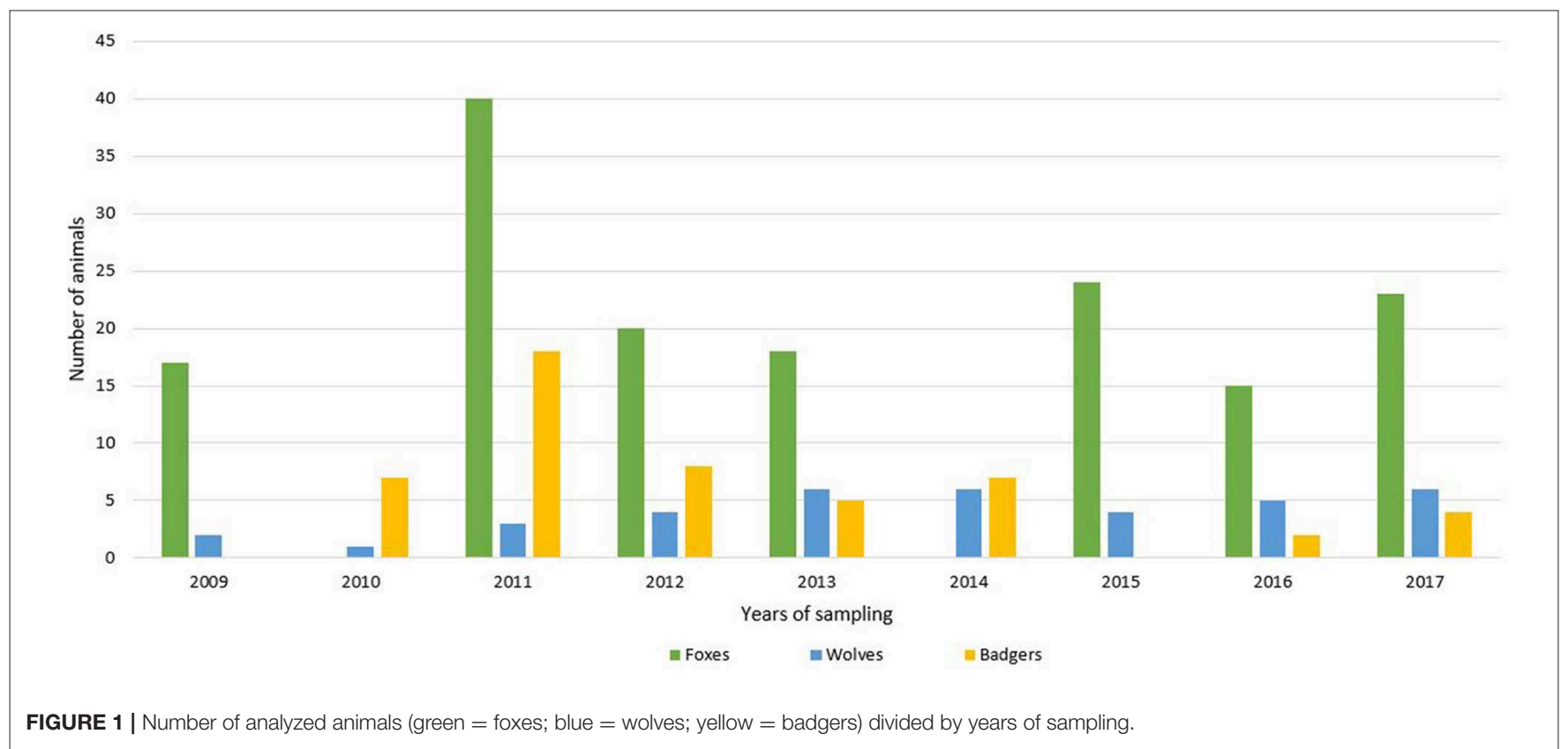


(mountain/flat/hill region) were recorded (Table 1). Spleen was collected from each animal and individually stored at $-20^{\circ} \mathrm{C}$ until further analysis.

Figure 2 shows the spatial distribution of the sampled animals.

\section{Molecular and Statistical Analysis}

DNA was extracted from $\approx 10 \mathrm{mg}$ of tissue by using the commercial kit GenElute Mammalian Genome DNA Miniprep (Sigma-Aldrich, St. Louis, MO, USA).

For Babesia detection, a semi-nested PCR targeting the V4 hypervariable region of the $18 \mathrm{~S}$ rRNA using primers RLB-F2 ( $5^{\prime}$ GACACAGGGAGGTAGTGACAAG-3'), RLB-R2 (5'-CTAAG AATTTCACCTCTGACAGT- $3^{\prime}$ ) and RLB-FINT (5'-GACAA GAAATAACAATACRGGGC-3') was performed (21). Briefly, the reaction mixture for the first step contained 1X of PCR Master Mix (Promega Corporation, WI, USA), 20 pmol of each primer and $5 \mu \mathrm{l}$ of DNA, in an overall volume of $25 \mu \mathrm{l}$. The thermal cycler conditions used were an initial denaturation step at $95^{\circ} \mathrm{C}$ for $5 \mathrm{~min}$, followed by $25 \mathrm{cycles}$ at $95^{\circ} \mathrm{C}$ for $30 \mathrm{~s}, 50^{\circ} \mathrm{C}$ for $45 \mathrm{~s}$ and $72^{\circ} \mathrm{C}$ for $90 \mathrm{~s}$, and a final elongation step at $72^{\circ} \mathrm{C}$ for $10 \mathrm{~min}$. Amplicons from the first step $(1 \mu \mathrm{l})$ were used as templates for the second step with internal primer RLB-FINT instead of RLBF2. Protocol and thermal cycler conditions were identical to the first step except for the annealing temperature at $55^{\circ} \mathrm{C}$ and for the cycling number of 40 .

For Hepatozoon detection, the $18 \mathrm{~S}$ rRNA was targeted by using primers HepF (5'-ATACATGAGCAAAATCTCAAC$\left.3^{\prime}\right)$ and HepR (5'-CTTATTATTCCATGCTGCAG-3') (26). The reaction contained $12.5 \mu \mathrm{l}$ of Taq PCR Master Mix (Qiagen, Hilden, Germany), $50 \mathrm{pmol}$ of each primer and $2 \mu \mathrm{l}$ of DNA, for

TABLE 1 | Analyzed species divided by age and sex.

\begin{tabular}{|c|c|c|c|c|}
\hline Species & Age & No of animals & Sex & No of animals \\
\hline \multirow[t]{6}{*}{ Red fox (Vulpes vulpes) } & $<1$ year & 2 & M & 1 \\
\hline & & & $\mathrm{F}$ & 1 \\
\hline & $1-2$ years & 53 & M & 13 \\
\hline & & & $\mathrm{F}$ & 40 \\
\hline & $>2$ years & 102 & $M$ & 47 \\
\hline & & & $\mathrm{F}$ & 55 \\
\hline \multirow[t]{6}{*}{ Wolf (Canis lupus) } & $<1$ year & 9 & M & 2 \\
\hline & & & $\mathrm{F}$ & 7 \\
\hline & $1-2$ years & 13 & $\mathrm{M}$ & 6 \\
\hline & & & $\mathrm{F}$ & 7 \\
\hline & $>2$ years & 11 & M & 9 \\
\hline & & & $\mathrm{F}$ & 2 \\
\hline \multirow[t]{6}{*}{ Badger (Meles meles) } & $<1$ year & 0 & M & 0 \\
\hline & & & $\mathrm{F}$ & 0 \\
\hline & 1-2 years & 14 & $M$ & 12 \\
\hline & & & $\mathrm{F}$ & 8 \\
\hline & $>2$ years & 31 & M & 11 \\
\hline & & & $\mathrm{F}$ & 14 \\
\hline
\end{tabular}

an overall volume of $25 \mu$. Thermal cycler conditions were $95^{\circ} \mathrm{C}$ for $5 \mathrm{~min}$, followed by 35 cycles at $94^{\circ} \mathrm{C}$ for $1 \mathrm{~min}, 53^{\circ} \mathrm{C}$ for $30 \mathrm{~s}$, $72^{\circ} \mathrm{C}$ for $1 \mathrm{~min}$, and a final elongation step at $72^{\circ} \mathrm{C}$ for $10 \mathrm{~min}$. Anaplasmataceae were detected with conventional PCR by using primers PER1 (5'-TTTATCGCTATTAGATGAGCCTATG-3') and PER2 (5'-CTCTACACTAGGAATTCCGCTAT- $\left.3^{\prime}\right)$ targeting the $16 \mathrm{~S}$ rRNA of the bacteria (27). The PCR reaction mixture contained 1X of PCR buffer, 25 pmol of each primer, $0.5 \mathrm{mM}$ of $\mathrm{MgCl}$, 2.5 U of HotStarTaq DNA Polymerase (Qiagen, Hilden, Germany), $0.2 \mathrm{mM}$ of dNTPs mix (Sigma-Aldrich, St. Louis, MO, USA) and $1 \mu \mathrm{l}$ of DNA, in a total volume of $25 \mu \mathrm{l}$. The thermal cycler conditions were an initial denaturation step at $95^{\circ} \mathrm{C}$ for $15 \mathrm{~min}$, followed by 40 cycles at $94^{\circ} \mathrm{C}$ for $1 \mathrm{~min}, 52.4^{\circ} \mathrm{C}$ for $45 \mathrm{~s}$, $72^{\circ} \mathrm{C}$ for $1 \mathrm{~min}$ and a final elongation step at $72^{\circ} \mathrm{C}$ for $10 \mathrm{~min}$.

Leishmania infantum was detected by amplifying a fragment of the highly reiterated minicircles of $\mathrm{kDNA}$ with primers RV1 (5'-CTTTTCTGGTCCCGCGGGTAGG-3') and RV2 $\left(5^{\prime}\right.$-CCACCTGGCCTATTTTACACCA-3') (28). Briefly, the reaction mixture contained $1 \mathrm{X}$ of $\mathrm{PCR}$ buffer, $22.5 \mathrm{pmol}$ of

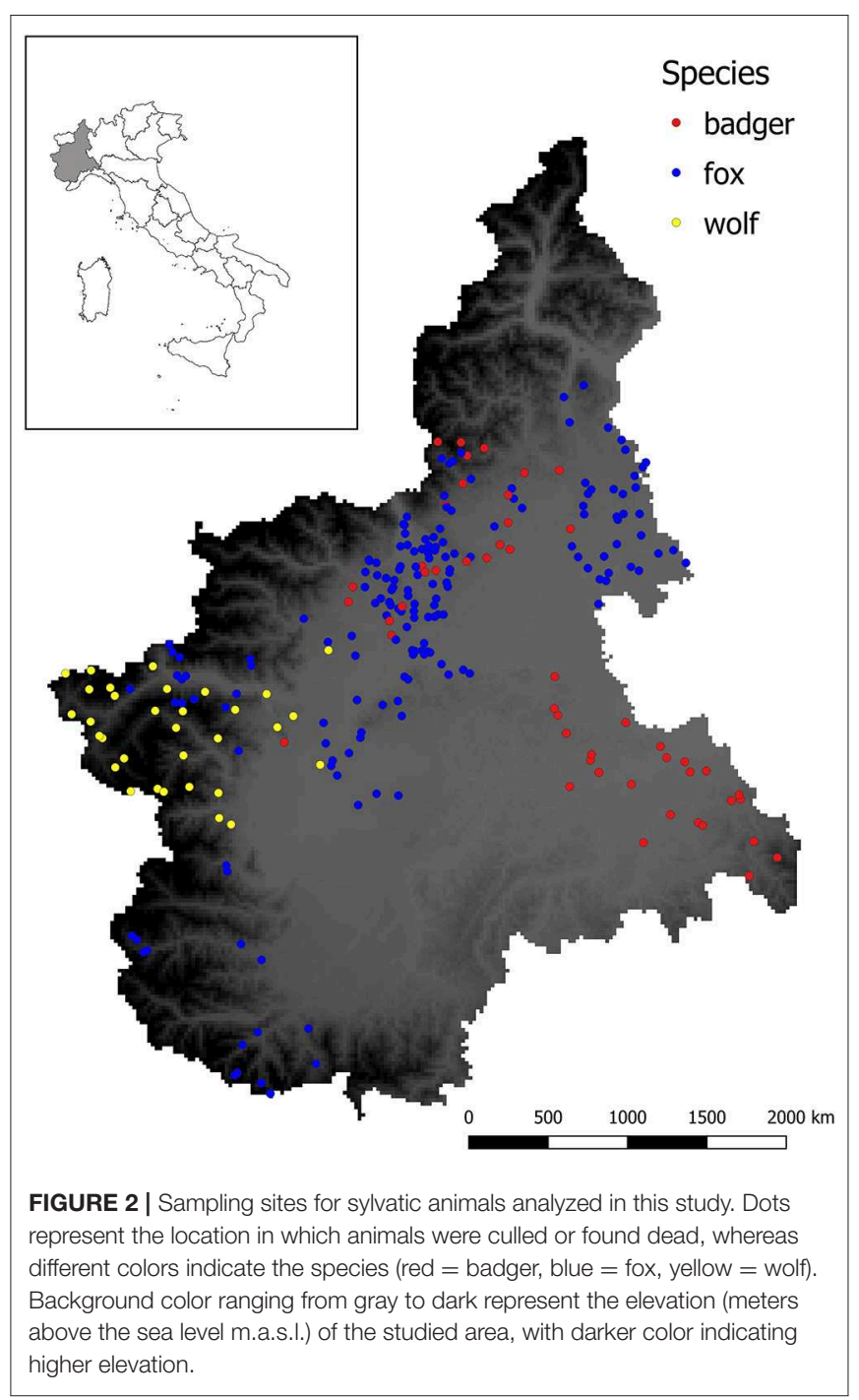


each primer, 2.5 U of HotStarTaq DNA Polymerase (Qiagen, Hilden, Germany), $0.2 \mathrm{mM}$ of dNTPs mix (Sigma-Aldrich, St. Louis, MO, USA) and $2.5 \mu \mathrm{l}$ of DNA, in a total volume of $25 \mu \mathrm{l}$. Thermal cycler conditions were $95^{\circ} \mathrm{C}$ for $15 \mathrm{~min}, 45$ cycles of $94^{\circ} \mathrm{C}$ for $1 \mathrm{~min}, 62^{\circ} \mathrm{C}$ for $1.5 \mathrm{~min}$ and $72^{\circ} \mathrm{C}$ for $1 \mathrm{~min}$, and a final elongation step of $72^{\circ} \mathrm{C}$ for $10 \mathrm{~min}$.

For each PCR, positive and negative controls were processed together with samples and all the precautions were taken to minimize the risk of contamination.

Selected positive amplicons were purified using a commercial kit (Nucleospin Extract II Kit, Macherey-Nagel, Düren, Germany) and sequenced (Macrogen Europe, The Netherland).

Logistic regression was performed by using R software (3.5.1) (29), to investigate possible risk factors for TBD infection (age, sex, area of origin and year of sampling). Map showing the distribution of sampled animals was performed by using GIS (3.2) (30).

\section{RESULTS}

\section{Prevalence of VBPs}

DNA of at least one target pathogen was detected in $93.6 \%$ [220/235] of the analyzed animals (Table 2). In particular, $94.9 \%$ of the foxes [149/157], 84.8\% [28/33] of the wolves and $95.6 \%$ [43/45] of the badgers tested positive for any of the analyzed vector-borne pathogen (VBP).

The prevalence of Babesia spp. was significantly higher $(p<0.05)$ in foxes $(89.7 \%$, CI95\% 83.63-93.63\%) [130/145] and badgers (91.1\%, CI95\% 79.27-96.49\%) [41/45] than in wolves
(39.4\%, CI95\% 24.68-56.32\%) [13/33], while Hepatozoon spp. showed higher prevalence $(p<0.05)$ in wolves $(75.76 \%$, CI95\% $58.98-87.17 \%)$ [25/33] than foxes (5.1\%, CI95\% 2.62-9.79\%) [8/156]. None of the badgers tested positive for Hepatozoon spp., although they showed higher prevalence $(p<0.05)$ of Anaplasmataceae infection (62.22\%, CI95\% 47.63-74.89\%) [28/45] and L. infantum DNA (53.33\%, CI95\% 39.08-67.06\%) [24/45] than in the other two species (see Table 2).

\section{Sequencing Results}

Results of the sequencing are listed in Table 3. Among the positive samples, 115 amplicons were chosen for sequencing due to the high quality of the PCR products.

In foxes, $B$. vulpes was the most prevalent species $(10.34 \%$, CI95\% 6.37-16.37\%), with sequences showing $99-100 \%$ of similarity with a sequence described by Duscher and colleagues (31) in hunted foxes from Austria [GenBank: KM115977]. One fox tested positive for Babesia sp. DO23163 (0.69\%, CI95\% $0.12-3.80 \%$ ), with sequence showing $100 \%$ similarity to a sequence obtained from a racoon dog in Osaka, Japan [GenBank: AB935167]. Moreover, 8 foxes tested positive for $H$. canis, and sequences showed $100 \%$ similarity with $H$. canis described in hunting dogs from the Czech Republic (32) [GenBank: KU893127]. Three wolves were found to be infected by $B$. capreoli, whose sequence were $100 \%$ similar to B. capreoli [GenBank: KX839234] identified in horses from Northwestern Italy (33), and 21 by $H$. canis. Sequences of $H$. canis obtained in wolves showed $97-100 \%$ similarity to those described in hunting dogs from the Czech Republic (32) [GenBank: KU893127], in

TABLE 2 | Prevalence and confidence intervals (C195\%) of the analyzed VBPs divided by species.

\begin{tabular}{|c|c|c|c|c|}
\hline \multirow[t]{2}{*}{ Species } & \multicolumn{4}{|c|}{ Prevalence (Confidence Interval 95\%) } \\
\hline & Babesia spp. & Anaplasmataceae & Hepatozoon spp. & Leishmania infantum \\
\hline Red fox (Vulpes vulpes) & 89.7\% (83.63-93.63\%) & $10.97 \%(6.96-16.86)$ & $5.1 \%(2.62-9.79 \%)$ & $12.26 \%(7.99-18.35)$ \\
\hline Wolf (Canis lupus) & $39.4 \%(24.68-56.32 \%)$ & $11.43 \%(4.54-25.95)$ & $75.76 \%$ (58.98-87.17\%) & $25.00 \%(12.68-43.36 \%)$ \\
\hline European badger (Meles meles) & $91.1 \%(79.27-96.49 \%)$ & $62.22 \%(47.63-74.89 \%)$ & $0 \%(0.00-7.87 \%)$ & $53.33 \%(39.08-67.06 \%)$ \\
\hline
\end{tabular}

TABLE 3 | Prevalence, confidence intervals, and identity of each sequenced pathogen divided by host species.

\begin{tabular}{|c|c|c|c|c|c|c|}
\hline Pathogen species & Host species & Sequenced amplicons & Prevalence & Confidence Interval (95\%) & Percent Identity & GenBank Accession Number \\
\hline B. vulpes & Fox & 15 & $10.34 \%$ & $6.37-16.37$ & $99-100 \%$ & KM115977 \\
\hline B. sp DO23163 & Fox & 1 & $0.69 \%$ & $0.12-3.80$ & $100 \%$ & AB935167 \\
\hline \multirow[t]{2}{*}{ B. capreoli } & Wolf & 3 & $9.09 \%$ & $3.14-23.57$ & $100 \%$ & KX839234 \\
\hline & Badger & 1 & $2.22 \%$ & $0.39-11.57$ & $100 \%$ & KX839234 \\
\hline B. badger type $A$ & Badger & 7 & $15.56 \%$ & $7.75-28.78$ & $100 \%$ & KX528553 \\
\hline B. badger type $B$ & Badger & 1 & $2.22 \%$ & $0.39-11.57$ & $100 \%$ & KT223485 \\
\hline A. phagocytophilum & Badger & 3 & $6.67 \%$ & $2.29-17.86$ & $100 \%$ & KC800985 \\
\hline Ehrlichia sp. & Badger & 5 & $11.11 \%$ & $4.84-23.50$ & $99 \%$ & KR262717 \\
\hline \multirow[t]{2}{*}{ H. canis } & Fox & 8 & $5.13 \%$ & $2.62-9.79$ & $100 \%$ & KU893127 \\
\hline & Wolf & 21 & $63.64 \%$ & $46.62-77.81$ & $100 \%$ & KU893127 \\
\hline \multirow[t]{3}{*}{ L. infantum } & Fox & 19 & $12.26 \%$ & 7.99-18.35 & $100 \%$ & HF937257 \\
\hline & Wolf & 7 & $25.71 \%$ & $14.16-42.07$ & $100 \%$ & HF937257 \\
\hline & Badger & 24 & $53.33 \%$ & 39.08-67.06 & $100 \%$ & HF937257 \\
\hline
\end{tabular}


Eurasian golden jackals from Austria (34) [KX712123], and in foxes and ticks from Italy (35) [GenBank: GU371448]. Regarding badgers, Babesia sp. isolate badger type A was the most prevalent recorded piroplasm (15.56\%, CI95\% 7.75-28.78\%), followed by Babesia sp. DO23163 (4.44\%, CI95\% 1.23-14.83\%), Babesia sp. isolate badger type B (2.22\%, CI95\% 0.39-11.57\%) and B. capreoli (2.22\%, CI95\% 0.39-11.57\%). Babesia sp. isolate badger type A sequences showed $100 \%$ similarity to a sequence described by Bartley and colleagues (36) in badgers from Scotland [GenBank: KX528553], while the positive samples for Babesia sp. DO23163 showed $100 \%$ similarity with the sequence we found in one fox in this study. Babesia sp. isolate badger type B, found in one badger, was $100 \%$ similar to a sequence described by Barandika and colleagues (14) in badgers from Northern Spain [GenBank: KT223485], while B. capreoli was $100 \%$ similar to $B$. capreoli identified in 3 wolves from this study and horses from Northwestern Italy (33). Finally, A. phagocytophilum was detected in 3 badgers out of 8 samples sequenced $(6.67 \%$, CI95\% $2.29-17.86 \%$ ), while 5 isolates showed $99 \%$ similarity with a novel Ehrlichia sp. found in a badger in Northern Spain (37) [GenBank: KR262717]. None of the Anaplasmataceae positive samples obtained from foxes and wolves were sequenced due to the poor quality of the amplicons. Amplicons of L. infantum recovered from the animals in this study were sequenced for species confirmation and showed $100 \%$ similarity with those deposited (e.g., GenBank:HF937257 from Italy).

Logistic regression showed higher risk of infection for animals collected in flat or hilly areas (below $600 \mathrm{~m}$ a.s.l.) than in mountain areas (above $600 \mathrm{~m}$ a.s.l.) (AUC $=0.79)$. In particular, higher risk of Anaplasmataceae infection in foxes $(p<0.05$; OR $=7.16)$ and of Babesia sp. in badgers $(p<0.01$; OR $=22.50)$ was recorded.

\section{DISCUSSION}

With $23 \%$ of emerging infectious diseases actually transmitted by arthropods, vector-borne pathogens have a considerable impact on human health (1). Several factors have been implicated in this emergence; among others, the increase of human encroachment into wild habitats, climate change and the consequent territorial expansion of vector arthropods are the most important $(38,39)$.

The recent increase of some wildlife populations (38) is expected to influence the epidemiology of vector-borne diseases, as several sylvatic species are known or suspected reservoirs of VBPs.

Few data are available on VBP presence and prevalence in carnivorans from the alpine region (21). In our study, the prevalence of Babesia in foxes is one of the highest reported so far in Europe. Similar prevalence has been found in Portugal, where Cardoso and colleagues have reported a prevalence ranging from 78 to $100 \%$, depending on the type of sample (blood or bone marrow) and the analyzed area (northern or southern part of the country) (39). Lower prevalence has been detected in Spain (40), Germany (41), Hungary (42) and Slovakia (43) (72.2, 46.4, 20, and $9.7 \%$, respectively). In Italy, previous findings have showed variable results depending on the geographical area, ranging from
$<1$ to $54 \%(21-23,44)$. Most of the foxes in the present study were found to be infected with $B$. vulpes, as already reported in Spain (45), Italy (46), Croatia (47), Germany (41), Portugal (39), and Austria (31). Despite the severe symptomatology reported in dogs infected with B. vulpes (48-50), only one case of symptomatic infection in a fox has been reported so far (51). This finding, together with the high rate of infection reported, may indicate a role of foxes in the sylvatic cycle of this parasite, although more evidences are needed. To date, no proven tick vectors for $B$. vulpes have been observed. The hedgehog tick Ixodes hexagonus has been proposed as the main vector of this parasite based solely on the association between the occurrence of this tick and the infection in dogs (52). Moreover, the detection of B. vulpes DNA in unfed Dermacentor reticulatus ticks in Austria (53) may suggest a possible role of this tick species as well. In the study area, both $I$. hexagonus and $D$. reticulatus have been described infesting privately owned dogs (54).

To the best of our knowledge, only two previous studies have investigated the occurrence of Babesia spp. in free-ranging wolves in Europe, reporting a prevalence of $20 \%$ in Croatia (10) and $7 \%$ in Italy (23). Similar to the present study, Beck and colleagues (10) reported the presence of wolves infected by piroplasms having wild ungulates as natural hosts. In particular, we detected B. capreoli DNA in 3 wolf samples, with sequences showing $100 \%$ similarity to those reported from sympatric roe deer, red deer, horses and ticks collected from owned dogs $(21,33)$. Additionally, the same parasite was also found in 1 badger from this study, suggesting a broader host specificity for $B$. capreoli than previously observed. However, due to the limited number of sequenced amplicons, we are not able to speculate any further, and more studies are needed in order to better understand the role of wolves and badgers in the epidemiology of this Babesia species. Moreover, most of the badgers and one positive fox were infected with mustelid-related Babesia species, such as Babesia sp. DO23163, Babesia sp. badger type A and type B $(13,14,36)$ that belong to the B. microti group (13). In Italy, badger-associated Babesia infection has been observed also in a wolf from Southern Italy (23), highlighting the circulation of these species within wild carnivorans of the order Caniformia.

Hepatozoon canis was the only Hepatozoon species detected, with $5 \%$ of prevalence in foxes and more than $75 \%$ in wolves. Previous reports of $H$. canis in foxes from Italy (35), Croatia (47), Bosnia and Herzegovina (11), and Spain $(18,55)$ showed a prevalence ranging from $13 \%$ up to $90 \%$, while to the best of our knowledge this is the first epidemiological study investigating the occurrence of this parasite in free-ranging wolves. In contrast to Babesia, infection with $H$. canis is acquired by the mammal host through the ingestion of an infected tick rather than tick bite. The main vector of this parasite is Rhipicephalus sanguineus s.l., the kennel tick, which is widely distributed in Southern Europe and strongly associated with dog presence (56). However, the occurrence of $H$. canis has been reported in wildlife from areas in which $R$. sanguineus s.l. is not endemic such as Austria (57), Slovakia (58), and Germany (59), suggesting the role of other tick species as vectors of $H$. canis. To date, only Rhipicephalus turanicus has been considered as an additional definitive host for this parasite (60), while Dermacentor spp., Haemaphysalis 
concinna and Ixodes ricinus have proved to harbor parasite DNA $(35,61)$. In Northern Italy, both the proved and the suspected vectors of $H$. canis have been reported in dogs (54) and humans (62). Predation has been proved to be an alternative route for Hepatozoon americanum infection, a closely related species endemic in the United States (63), thus suggesting a similar transmission way for $H$. canis. In particular, the consumption of infected carrions and prey such as rodents carrying tissue cysts of the parasite may be a possible infection route for both wild and domestic carnivores (e.g., shepherd and hunting dogs) (61). Finally, transplacental transmission of $H$. canis has been proved in dogs (64) and foxes (65).

Several studies have investigated the prevalence of Anaplasmataceae in wild carnivorans, showing considerable differences among the animal species. In foxes, the occurrence of these bacteria has been previously investigated in Italy (17), Germany (66), Poland (67), The Netherland (68), Romania (69), Switzerland (70), Czech Republic (71), Austria (65), Hungary (16), and Spain (37), with results that are in line with our findings. In contrast to the red fox, badgers and wolves have been less investigated in Europe. No badgers showed positivity for $A$. phagocytophilum in The Netherland (68), Czech Republic (71), and Spain (72), where negative results have been obtained also for the wolf (37). Notably, out of 114 badgers only two were found positive during a study on the occurrence of VBPs in mustelids from Belgium and The Netherland (73). The prevalence of $A$. phagocytophilum obtained in the present study is in line with that reported previously, showing low occurrence of this bacterium in badger and maybe suggesting the poor role of this mustelid species in the epidemiology of Anaplasmataceae. Conversely, additional studies are needed to further investigate the presence of this bacteria in the wolf, due to limited existing information.

More than half of the badgers in our survey tested positive for $L$. infantum, while the prevalence in the other two species is significantly lower ( $25.71 \%$ in wolves and $12.26 \%$ in foxes). The occurrence of $L$. infantum has been largely assessed in free-ranging carnivorans, especially in canids, due to their phylogenetic closeness to dogs that are the main reservoir of this parasite (20). The prevalence of L. infantum found in foxes in this study, although lower than reported previously in Central and Southern Italy $(74,75)$, confirms the recently established endemic area of transmission in Northern Italy where autochthonous dogs showed more than $40 \%$ of seroprevalence (24). The prevalence in foxes from Spain ranges from 14\% (76) to $75 \%$ (77), while in Portugal the prevalence is much lower $(78,79)$. Although several studies have been performed in order to detect L. infantum in wolves in Europe $(76,80,81)$, to our knowledge this is the first epidemiological study on this parasite in the Italian wolf population. Our results are in line with those obtained from Spain (81), suggesting a similar epidemiological situation. Compared with foxes and wolves, the presence of $L$. infantum in badgers has been generally less evaluated. However, the moderate to high prevalence observed in this and other studies $(81,82)$ could suggest a role of this species in the epidemiology of L. infantum, at least in its sylvatic life cycle. Nevertheless, further studies are needed to assess the capacity of badgers to infect sandflies, a fundamental ability for a competent reservoir (20).
Statistical analysis of risk factors showed a higher risk of Anaplasmataceae infection in foxes and of Babesia spp. in badgers collected in flat or hilly areas (below $600 \mathrm{~m}$ a.s.l.) than in mountain areas (above $600 \mathrm{~m}$ a.s.l.). This could be accounted to higher abundance of vectors (Ixodid ticks) in hilly areas than in the mountains due to more suitable environmental characteristics and to a higher presence of other sylvatic hosts for ticks as wild ungulates.

\section{CONCLUSIONS}

With the molecular analysis of 235 specimens collected from 2009 to 2017, this study provides valuable information about the situation of vector-borne pathogens in wild carnivorans from Northwestern Italy, showing high level of infection in all target species. Moreover, we reported for the first time the presence of $B$. capreoli in wolves and badgers, two unexpected hosts for this parasite, and of $H$. canis in wolves.

This survey highlights the presence of several VBP in the study area, many of which capable to infect domestic animals and humans. The high occurrence of VBPs in sylvatic carnivorans could pose a risk for both animal and human health, especially in an area with growing urbanization and increasing wildlife population as in many parts of Europe, that lead humans, wildlife, livestock and pets to closer contacts.

\section{DATA AVAILABILITY STATEMENT}

All datasets generated and analyzed for this study are included in the article/supplementary material.

\section{ETHICS STATEMENT}

Ethical approval was obtained by the Ethical committees of the Department of Veterinary Sciences, University of Turin.

\section{AUTHOR CONTRIBUTIONS}

EB supervised the data collection, participated in data acquisition, and draft the manuscript. SZ supervised the data collection, undertook statistical analysis, and critically reviewed the manuscript. SK, $\mathrm{AT}$, and $\mathrm{BH}$ participated in data acquisition and helped to draft the manuscript. EF conceived the study, coordinated, and supervised the lab force and critically reviewed the manuscript. All authors read and approved the final manuscript.

\section{FUNDING}

This work was partially funded by the Regional Administration (Convenzione tra la Regione Piemonte e il Dipartimento di Scienze Veterinarie dell'Università degli Studi di Torino per la razionalizzazione ed integrazione delle attività di raccolta e smaltimento degli animali selvatici morti o oggetto di interventi di contenimento). 


\section{REFERENCES}

1. Jones KE, Patel NG, Levy MA, Storeygard A, Balk D, Gittleman JL, et al. Global trends in emerging infectious diseases. Nature. (2008) 451:990-3. doi: $10.1038 /$ nature06536

2. Mackenstedt U, Jenkins D, Romig T. The role of wildlife in the transmission of parasitic zoonoses in peri-urban and urban areas. Int J Parasitol Parasites Wildl. (2015) 4:71-9. doi: 10.1016/j.ijppaw.2015.01.006

3. Cleaveland S, Laurenson MK, Taylor LH. Diseases of humans and their domestic mammals: Pathogen characteristics, host range and the risk of emergence. Philos Trans R Soc B Biol Sci. (2001) 356:991-9. doi: 10.1098/rstb.2001.0889

4. Kruse H, Kirkemo AM, Handeland K. Wildlife as source of zoonotic infections. Emerg Infect Dis. (2004) 10:2067-72. doi: 10.3201/eid1012.040707

5. Bateman PW, Fleming PA. Big city life: Carnivores in urban environments. $J$ Zool. (2012) 287:1-23. doi: 10.1111/j.1469-7998.2011.00887.x

6. Chapron G, Huber D, Andrén H, López-bao JV, Adamec M, Linnell JDC, et al. Recovery of large carnivores in Europe's modern human-dominated landscapes. Science. (2014) 346:17-20. doi: 10.1126/science.1257553

7. Kilpatrick AM, Randolph SE. Drivers, dynamics, and control of emerging vector-borne zoonotic diseases. Lancet. (2012) 380:1946-55. doi: 10.1016/S0140-6736(12)61151-9

8. Alvarado-Rybak M, Solano-Gallego L, Millán J. A review of piroplasmid infections in wild carnivores worldwide: importance for domestic animal health and wildlife conservation. Parasites Vectors. (2016) 9:1-19. doi: 10.1186/s13071-016-1808-7

9. Solano-Gallego L, Sainz Á, Roura X, Estrada-Peña A, Miró G. A review of canine babesiosis: the European perspective. Parasit Vectors. (2016) 9:336. doi: 10.1186/s13071-016-1596-0

10. Beck A, Huber D, Polkinghorne A, Kurilj AG, Benko V, Mrljak V, et al. The prevalence and impact of Babesia canis and Theileria sp. in free-ranging grey wolf (Canis lupus) populations in Croatia. Parasites Vectors. (2017) 10:1-9. doi: 10.1186/s13071-017-2106-8

11. HodŽić A, Alić A, Fuehrer HP, Harl J, Wille-Piazzai W, Duscher GG. A molecular survey of vector-borne pathogens in red foxes (Vulpes vulpes) from Bosnia and Herzegovina. Parasites Vectors. (2015) 8:1-7. doi: 10.1186/s13071-015-0692-x

12. Baneth G, Florin-Christensen M, Cardoso L, Schnittger L. Reclassification of theileria annae as Babesia vulpes sp. nov. Parasit Vectors. (2015) 8:207. doi: 10.1186/s13071-015-0830-5

13. Hornok S, Horváth G, Takács N, Kontschán J, Szoke K, Farkas R. Molecular identification of badger-associated Babesia sp. DNA in dogs: updated phylogeny of piroplasms infecting Caniformia. Parasites Vectors. (2018) 11:16. doi: 10.1186/s13071-018-2794-8

14. Barandika JF, Espì A, Oporto B, Del Cerro A, Barral M, Povedano I, et al. Occurrence and genetic diversity of piroplasms and other apicomplexa in wild carnivores. Parasitol Open. (2016) 2:1-7. doi: 10.1017/pao.2016.4

15. Smith TG. The genus hepatozoon (Apicomplexa: Adeleina). J Parasitol. (1996) 82:565-85. doi: $10.2307 / 3283781$

16. Tolnai Z, Sréter-Lancz Z, Sréter T. Spatial distribution of Anaplasma phagocytophilum and Hepatozoon canis in red foxes (Vulpes vulpes) in Hungary. Ticks Tick Borne Dis. (2015) 6:645-8. doi: 10.1016/j.ttbdis.2015.05.009

17. Ebani VV, Verin R, Fratini F, Poli A, Cerri D. Molecular survey of Anaplasma phagocytophilum and Ehrlichia canis in red foxes (Vulpes vulpes) from central Italy. J Wildl Dis. (2011) 47:699-703. doi: 10.7589/0090-3558-47.3.699

18. Criado-fornelio AA, Ruas JL, Casado N, Farias NAR, Soares MP, Brum JGW, et al. New molecular data on mammalian hepatozoon species (Apicomplexa: Adeleorina) from Brazil and Spain. J Parasitol. (2006) 92:93-9. doi: 10.1645/GE-464R.1

19. Molina R, Jiménez MI, Cruz I, Iriso A, Martín-Martín I, Sevillano O, et al. The hare (Lepus granatensis) as potential sylvatic reservoir of Leishmania infantum in Spain. Vet Parasitol. (2012) 190:268-71. doi: 10.1016/j.vetpar.2012.05.006

20. Millán J, Ferroglio E, Solano-Gallego L. Role of wildlife in the epidemiology of Leishmania infantum infection in Europe. Parasitol Res. (2014) 113:2005-14. doi: 10.1007/s00436-014-3929-2

21. Zanet S, Trisciuoglio A, Bottero E, De Mera IGF, Gortazar C, Carpignano MG, et al. Piroplasmosis in wildlife: Babesia and Theileria affecting free-ranging ungulates and carnivores in the Italian Alps. Parasites Vectors. (2014) 7:1-7. doi: 10.1186/1756-3305-7-70

22. Ebani VV, Rocchigiani G, Nardoni S, Bertelloni F, Vasta V, Papini RA, et al. Molecular detection of tick-borne pathogens in wild red foxes (Vulpes vulpes) from Central Italy. Acta Trop. (2017) 172:197-200. doi: 10.1016/j.actatropica.2017.05.014

23. Santoro M, Auriemma C, Lucibelli MG, Borriello G, D’Alessio N, Sgroi G, et al. Molecular detection of Babesia spp. (Apicomplexa: Piroplasma) in freeranging canids and mustelids from Southern Italy. Front Vet Sci. (2019) 6:269. doi: $10.3389 /$ fvets.2019.00269

24. Ferroglio E, Battisti E, Zanet S, Bolla C, Concialdi E, Trisciuoglio A, et al. Epidemiological evaluation of Leishmania infantum zoonotic transmission risk in the recently established endemic area of Northwestern Italy. Zoonoses Public Health. (2018) 65:675-82. doi: 10.1111/zph.12477

25. De Meneghi D. Wildlife, environment and (re)-emerging zoonoses, with special reference to sylvatic tick-borne zoonoses in North-western Italy. Ann Ist Super Sanita. (2006) 42:405-9.

26. Inokuma H, Okuda M, Ohno K, Shimoda K, Onishi T. Analysis of the $18 \mathrm{~S}$ rRNA gene sequence of a Hepatozoon detected in two Japanese dogs. Vet Parasitol. (2002) 106:265-71. doi: 10.1016/S0304-4017(02)00065-1

27. Goodman JL, Nelson C, Vitale B, Madigan JE, Dumler JS, Kurtti TJ, et al. Direct cultivation of the causative agent of human granulocytic ehrlichiosis. N Engl J Med. (1996) 334:209-15. doi: 10.1056/NEJM199601253340401

28. Ferroglio E, Romano A, Trisciuoglio A, Poggi M, Ghiggi E, Sacchi P, et al. Characterization of Leishmania infantum strains in blood samples from infected dogs and humans by PCR-RFLP. Trans R Soc Trop Med Hyg. (2006) 100:636-41. doi: 10.1016/j.trstmh.2005.09.008

29. R Development Core Team. R: A Language and Environment for Statistical Computing. Vienna: R Found Statistical Computing (2018).

30. QGIS Developmental Team. QGIS Geographic Information System. Open Source Geospatial Foundation Project (2018).

31. Duscher GG, Fuehrer HP, Kübber-Heiss A. Fox on the run - molecular surveillance of fox blood and tissue for the occurrence of tick-borne pathogens in Austria. Parasites Vectors. (2014) 7:1-4. doi: 10.1186/s13071-014-0521-7

32. Mitková B, Hrazdilová K, Steinbauer V, D’Amico G, Mihalca AD, Modrý D. Autochthonous Hepatozoon infection in hunting dogs and foxes from the Czech Republic. Parasitol Res. (2016) 115:4167-71. doi: 10.1007/s00436-016-5191-2

33. Zanet S, Bassano M, Trisciuoglio A, Taricco I, Ferroglio E. Horses infected by Piroplasms different from Babesia caballi and Theileria equi: species identification and risk factors analysis in Italy. Vet Parasitol. (2017) 236:38-41. doi: 10.1016/j.vetpar.2017.01.003

34. Mitková B, Hrazdilová K, D’Amico G, Duscher GG, Suchentrunk F, Forejtek P, et al. Eurasian golden jackal as host of canine vector-borne protists. Parasites Vectors. (2017) 10:1-11. doi: 10.1186/s13071-017-2110-Z

35. Gabrielli S, Kumlien S, Calderini P, Brozzi A, Iori A, Cancrini G. The first report of Hepatozoon canis identified in Vulpes vulpes and ticks from Italy. Vector-Borne Zoonotic Dis. (2010) 10:855-9. doi: 10.1089/vbz.2009.0182

36. Bartley PM, Wilson C, Innes EA, Katzer F. Detection of Babesia DNA in blood and spleen samples from Eurasian badgers (Meles meles) in Scotland. Parasitology. (2017) 144:1203-10. doi: 10.1017/S0031182017000476

37. García-Pérez AL, Oporto B, Espí A, del Cerro A, Barral M, Povedano I, et al. Anaplasmataceae in wild ungulates and carnivores in northern Spain. Ticks Tick Borne Dis. (2016) 7:264-9. doi: 10.1016/j.ttbdis.2015.10.019

38. Gortázar C, Ferroglio E, Höfle U, Frölich K, Vicente J. Diseases shared between wildlife and livestock: a European perspective. Eur J Wildl Res. (2007) 53:241-56. doi: 10.1007/s10344-007-0098-y

39. Cardoso L, Cortes HCE, Reis A, Rodrigues P, Simões M, Lopes AP, et al. Prevalence of Babesia microti-like infection in red foxes (Vulpes vulpes) from Portugal. Vet Parasitol. (2013) 196:90-5. doi: 10.1016/j.vetpar.2012.12.060

40. Checa R, López-Beceiro AM, Montoya A, Barrera JP, Ortega N, Gálvez R, et al. Babesia microti-like piroplasm (syn. Babesia vulpes) infection in red foxes (Vulpes vulpes) in NW Spain (Galicia) and its relationship with Ixodes hexagonus. Vet Parasitol. (2018) 252:22-8. doi: 10.1016/j.vetpar.2018.01.011

41. Najm NA, Meyer-Kayser E, Hoffmann L, Herb I, Fensterer V, Pfister K, et al. A molecular survey of Babesia spp. and Theileria spp. in red foxes (Vulpes vulpes) and their ticks from Thuringia, Germany. Ticks Tick Borne Dis. (2014) 5:386-91. doi: 10.1016/j.ttbdis.2014.01.005 
42. Farkas R, Takács N, Hornyák Á, Nachum-Biala Y, Hornok S, Baneth G. First report on Babesia cf. microti infection of red foxes (Vulpes vulpes) from Hungary. Parasites Vectors. (2015) 8:4-9. doi: 10.1186/s13071-015-0660-5

43. Koneval M, Miterpáková M, Hurníková Z, Blanarová L, Víchová B. Neglected intravascular pathogens, Babesia vulpes and haemotropic Mycoplasma spp. in European red fox (Vulpes vulpes) population. Vet Parasitol. (2017) 243:17682. doi: 10.1016/j.vetpar.2017.06.029

44. Da Rold G, Ravagnan S, Soppelsa F, Porcellato E, Soppelsa M, Obber F, et al. Ticks are more suitable than red foxes for monitoring zoonotic tickborne pathogens in northeastern Italy. Parasites Vectors. (2018) 11:1-10. doi: 10.1186/s13071-018-2726-7

45. Criado-Fornelio A, Martinez-Marcos A, Buling-Saraña A, Barba-Carretero JC. Molecular studies on Babesia, Theileria and Hepatozoon in southern Europe: Part I. Epizootiological aspects. Vet Parasitol. (2003) 113:189-201. doi: 10.1016/S0304-4017(03)00078-5

46. Tampieri MP, Galuppi R, Bonoli C, Cancrini G, Moretti A, Pietrobelli M. Wild ungulates as Babesia hosts in Northern and Central Italy. Vector-Borne Zoonotic Dis. (2008) 8:667-74. doi: 10.1089/vbz.2008.0001

47. Dezdek D, Vojta L, Curković S, Lipej Z, Mihaljević Ž, Cvetnić Ž, et al. Molecular detection of Theileria annae and Hepatozoon canis in foxes (Vulpes vulpes) in Croatia. Vet Parasitol. (2010) 172:333-6. doi: 10.1016/j.vetpar.2010.05.022

48. Guitián FJ, Camacho AT, Telford SR. Case-control study of canine infection by a newly recognised Babesia microti-like piroplasm. Prev Vet Med. (2003) 61:137-45. doi: 10.1016/S0167-5877(03)00164-8

49. Camacho AT, Guitian FJ, Pallas E, Gestal JJ, Olmeda AS, Goethert HK, et al. Azotemia and mortality among Babesia microti-like infected dogs. J Vet Intern Med. (2004) 18:141-6. doi: 10.1111/j.1939-1676.2004.tb00152.x

50. Camacho AT, Guitián FJ, Pallas E, Gestal JJ, Olmeda S, Goethert H, et al. Serum protein response and renal failure in canine Babesia annae infection. Vet Res. (2005) 36:713-22. doi: 10.1051/vetres:2005026

51. Clancey N, Horney B, Burton S, Birkenheuer A, McBurney S, Tefft K. Babesia (Theileria) annae in a Red Fox (Vulpes vulpes) from Prince Edward Island, Canada. J Wildl Dis. (2010) 46:615-21. doi: 10.7589/0090-3558-46.2.615

52. Camacho AT, Pallas E, Gestal JJ, Guitián FJ, Olmeda AS, Telford $\mathrm{SR}$, et al. Ixodes hexagonus is the main candidate as vector of Theileria annae in northwest Spain. Vet Parasitol. (2003) 112:11. doi: 10.1016/S0304-4017(02)00417-X

53. HodŽić A, Zörer J, Duscher GG. Dermacentor reticulatus, a putative vector of Babesia cf. microti (syn. Theileria annae) piroplasm. Parasitol Res. (2017) 116:1075-7. doi: 10.1007/s00436-017-5379-0

54. Maurelli MP, Pepe P, Colombo L, Armstrong R, Battisti E, Morgoglione ME, et al. A national survey of Ixodidae ticks on privately owned dogs in Italy. Parasites Vectors. (2018) 11:1-10. doi: 10.1186/s13071-018-2994-2

55. Gimenez C, Casado N, Criado-Fornelio Á, de Miguel FÁ, DominguezPeñafiel G. A molecular survey of Piroplasmida and Hepatozoon isolated from domestic and wild animals in Burgos (northern Spain). Vet Parasitol. (2009) 162:147-50. doi: 10.1016/j.vetpar.2009.02.021

56. Dantas-Torres F. Biology and ecology of the brown dog tick, Rhipicephalus sanguineus. Parasites Vectors. (2010) 3:1-11. doi: 10.1186/1756-3305-3-26

57. Duscher GG, Kübber-Heiss A, Richter B, Suchentrunk F. A golden jackal (Canis aureus) from Austria bearing Hepatozoon canis- import due to immigration into a non-endemic area? Ticks Tick Borne Dis. (2013) 4:133-7. doi: $10.1016 / j . t$ tbdis.2012.10.040

58. Majláthová V, Hurníková Z, Majláth I, Petko B. Hepatozoon canis infection in Slovakia: imported or autochthonous? Vector-Borne Zoonotic Dis. (2007) 7:199-202. doi: 10.1089/vbz.2006.0598

59. Najm NA, Meyer-Kayser E, Hoffmann L, Pfister K, Silaghi C. Hepatozoon canis in German red foxes (Vulpes vulpes) and their ticks: Molecular characterization and the phylogenetic relationship to other Hepatozoon spp. Parasitol Res. (2014) 113:2979-85. doi: 10.1007/s00436-014-3923-8

60. Giannelli A, Lia RP, Annoscia G, Buonavoglia C, Lorusso E, Dantas-Torres F, et al. Rhipicephalus turanicus, a new vector of Hepatozoon canis. Parasitology. (2017) 144:730-7. doi: 10.1017/S003118201600250X

61. Hornok S, Tánczos B, Fernández de Mera IG, de la Fuente J, HofmannLehmann R, Farkas R. High prevalence of Hepatozoon-infection among shepherd dogs in a region considered to be free of Rhipicephalus sanguineus. Vet Parasitol. (2013) 196:189-93. doi: 10.1016/j.vetpar.2013.02.009
62. Battisti E, Zanet S, Boraso F, Minniti D, Giacometti M, Duscher GG, et al. Survey on tick-borne pathogens in ticks removed from humans in Northwestern Italy. Vet Parasitol Reg Stud Reports. (2019) 18:100352. doi: 10.1016/j.vprsr.2019.100352

63. Johnson EM, Allen KE, Panciera RJ, Little SE, Ewing SA. Infectivity of Hepatozoon americanum cystozoites for a dog. Vet Parasitol. (2008) 154:14850. doi: 10.1016/j.vetpar.2008.02.026

64. Murata $T$, Inoue $M$, Tateyama S, Taura $Y$, Nakama S. Vertical transmission of Hepatozoon canis in dogs. J Vet Med Sci. (1993) 55:867-8. doi: 10.1292/jvms.55.867

65. HodŽic A, Mrowietz N, Cézanne R, Bruckschwaiger P, Punz S, Habler $\mathrm{VE}$, et al. Occurrence and diversity of arthropod-transmitted pathogens in red foxes (Vulpes vulpes) in western Austria, and possible vertical (transplacental) transmission of Hepatozoon canis. Parasitology. (2018) 145:335-44. doi: 10.1017/S0031182017001536

66. Härtwig V, von Loewenich FD, Schulze C, Straubinger RK, Daugschies A, Dyachenko V. Detection of Anaplasma phagocytophilum in red foxes (Vulpes vulpes) and raccoon dogs (Nyctereutes procyonoides) from Brandenburg, Germany. Ticks Tick Borne Dis. (2014) 5:277-80. doi: 10.1016/j.ttbdis.2013.11.001

67. Karbowiak G, Víchová B, Majláthová V, Hapunik J, Petko B. Anaplasma phagocytophilum infection of red foxes (Vulpes vulpes). Ann Agric Environ Med. (2009) 16:299-300.

68. Jahfari S, Coipan EC, Fonville M, Van Leeuwen AD, Hengeveld P, Heylen D, et al. Circulation of four Anaplasma phagocytophilum ecotypes in Europe. Parasites Vectors. (2014) 7:1-11. doi: 10.1186/1756-3305-7-365

69. Dumitrache MO, Matei IA, Ionicə AM, Kalmár Z, D’Amico G, Sikó-Barabási S, et al. Molecular detection of Anaplasma phagocytophilum and Borrelia burgdorferi sensu lato genospecies in red foxes (Vulpes vulpes) from Romania. Parasites Vectors. (2015) 8:1-5. doi: 10.1186/s13071-015-1130-9

70. Hofmann-Lehmann R, Wagmann N, Meli ML, Riond B, Novacco M, Joekel D, et al. Detection of 'Candidatus Neoehrlichia mikurensis' and other Anaplasmataceae and Rickettsiaceae in Canidae in Switzerland and Mediterranean countries. Schweiz Arch Tierheilkd. (2016) 158:691-700. doi: 10.17236/sat00087

71. HodŽić A, Mitkovà B, Modrý D, Juránková J, Frgelecová L, Forejtek P, et al. A new case of the enigmatic Candidatus Neoehrlichia sp. (FU98) in a fox from the Czech Republic. Mol Cell Probes. (2017) 31:59-60. doi: 10.1016/j.mcp.2016.02.005

72. Millán J, Proboste T, Fernández de Mera IG, Chirife AD, de la Fuente J, Altet L. Molecular detection of vector-borne pathogens in wild and domestic carnivores and their ticks at the human-wildlife interface. Ticks Tick Borne Dis. (2016) 7:284-90. doi: 10.1016/j.ttbdis.2015.11.003

73. Hofmeester TR, Krawczyk AI, Van Leeuwen AD, Fonville M, Montizaan MGE, Van Den Berge K, et al. Role of mustelids in the life-cycle of ixodid ticks and transmission cycles of four tick-borne pathogens. Parasites Vectors. (2018) 11:1-13. doi: 10.1186/s13071-018-3126-8

74. Dipineto L, Manna L, Baiano A, Gala M, Fioretti A, Gravino AE, et al. Presence of Leishmania infantum in Red Foxes (Vulpes vulpes) in Southern Italy. J Wildl Dis. (2007) 43:518-20. doi: 10.7589/0090-3558-43.3.518

75. Verin R, Poli A, Ariti G, Nardoni S, Fanucchi MB, Mancianti F. Detection of leishmania infantum DNA in tissues of free-ranging red foxes (vulpes vulpes) in Central italy. Eur J Wildl Res. (2010) 56:689-92. doi: 10.1007/s10344-010-0395-8

76. Sobrino R, Ferroglio E, Oleaga A, Romano A, Millan J, Revilla M, et al. Characterization of widespread canine leishmaniasis among wild carnivores from Spain. Vet Parasitol. (2008) 155:198-203. doi: 10.1016/j.vetpar.2008.05.003

77. Criado-Fornelio A, Gutierrez-Garcia L, Rodriguez-Caabeiro F, Reus-Garcia E, Roldan-Soriano MA, Diaz-Sanchez MA. A parasitological survey of wild red foxes (Vulpes vulpes) from the province of Guadalajara, Spain. Vet Parasitol. (2000) 92:245-51. doi: 10.1016/S0304-4017(00)00329-0

78. Abranches P, Lopes FJ, Fernandes PS, Gomes LT. Kala-azar in Portugal. I. Attempts to find a wild reservoir. J Trop Med Hyg. (1982) 85:123-6.

79. Abranches P, Silva FMC, Rlbeiro MMS, Lopes FJ, Gomes LT. Kala-azar in portugal-IV. The wild reservoir: the isolation of a Leishmania from a fox. Trans R Trop Med Hyg. (1983) 77:420-1. doi: 10.1016/0035-9203(83) 90177-3 
80. Beck A, Beck R, Kusak J, Gudan A, Martinković F, Artuković B, et al. A case of Visceral Leishmaniosis in a Gray Wolf (Canis lupus) from Croatia. J Wildl Dis. (2008) 44:451-6. doi: 10.7589/0090-3558-44.2.451

81. Oleaga A, Zanet S, Espí A, Pegoraro de Macedo MR, Gortázar C, Ferroglio E. Leishmania in wolves in northern Spain: a spreading zoonosis evidenced by wildlife sanitary surveillance. Vet Parasitol. (2018) 255:26-31. doi: 10.1016/j.vetpar.2018.03.015

82. Del Río L, Chitimia L, Cubas A, Victoriano I, De la Rúa P, Gerrikagoitia X, et al. Evidence for widespread Leishmania infantum infection among wild carnivores in L. infantum periendemic northern Spain. Prev Vet Med. (2014) 113:430-5. doi: 10.1016/j.prevetmed.2013.12.001
Conflict of Interest: The authors declare that the research was conducted in the absence of any commercial or financial relationships that could be construed as a potential conflict of interest.

Copyright $\odot 2020$ Battisti, Zanet, Khalili, Trisciuoglio, Hertel and Ferroglio. This is an open-access article distributed under the terms of the Creative Commons Attribution License (CC BY). The use, distribution or reproduction in other forums is permitted, provided the original author(s) and the copyright owner(s) are credited and that the original publication in this journal is cited, in accordance with accepted academic practice. No use, distribution or reproduction is permitted which does not comply with these terms. 